\title{
Selected cytostatic drugs in the treatment of brain glioma - literature review
}

\section{Wybrane leki cytostatyczne w leczeniu glejaka mózgu - przegląd literatury}

\author{
Jarosław Bała ${ }^{1, B-D}$, Kinga Mitruczuk ${ }^{1, B-D}$, Natalia Walo ${ }^{1, B-D}$, Paula Wróblewska-Łuczka ${ }^{1, A, E-F}$ \\ ${ }^{1}$ Department of Pathophysiology, Medical University, Lublin, Poland \\ A - Research concept and design, B - Collection and/or assembly of data, C - Data analysis and interpretation, \\ $D$ - Writing the article, E - Critical revision of the article, F- Final approval of the article
}

Bała J, Mitruczuk K, Walo N, Wróblewska-Łuczka P. Selected cytostatic drugs in the treatment of brain glioma - literature review. Med Og Nauk Zdr. 2021; 27(4): 414-420. doi: 10.26444/monz/143811

\section{Abstract}

Introduction and objective. Gliomas are a highly heterogenous group of tumours of the nervous system. They are characterized by a varied course of disease. Depending on the cancer stage, they affect overall survival and progression-free survival. In view of the varied disease course, an individualized chemotherapeutic regimen is the most significant treatment.The aim of the study is to present up-to-date information on the most important cytostatic drugs used in the treatment of glioma.

Review methods. A review of previous knowledge and the latest scientific reports was undertaken using the publication databases PubMed, Web of Science and Scopus, focusing mainly on articles from the last five years. The key words and their combinations used for the search were consistent with the MeSH browser: glioma, cytostatic agents, temozolomide, procarbazine, lomustine, vincristine, bevacizumab.

Brief description of the state of knowledge. In the treatment of gliomas, temozolomide, lomustine, procarbazine, vincristine and bevacizumab are used. Combination therapy based on multi-drug regimens or chemotherapy combined with radiation therapy is also often used. Current therapies include cytostatic drugs, such temozolomide (TMZ), combination therapy with vincristine (VCR), lomustine (CNNU) and procarbazine, which is referred to as PCV therapy. The review includes the most important and recent information of chemotherapeutic drugs used in the treatment of gliomas i.e.: temozolomide, lomustine, procarbazine, vincristine and bevacizumab. The review contains information about the mechanisms of action, current scientific studies on combination therap, and potential adverse effects of the described drugs.

Summary. The latest results of drug interaction studies confirm the need for further research into combination therapy regimens using both newl-discovered therapeutics and combinations of already known drugs.

\section{Key words}

glioma, temozolomide, procarbazine, lomustine, vincristine, bevacizumab

\section{Abbreviation \\ ASR - Age-standardized incidence rate; BEV - Bevacizumab; CCNU - Lomustine; FDA - Food and Drug Administration;}

Address for correspondence: Paula Wróblewska-Łuczka, Department of Pathophysiology, Medical University, Lublin, Poland

E-mail: paula.luczka@umlub.pl

Received: 27.04.2021; accepted: 08.11.2021; first published: 19.11.2021
GM-CSF - Granulocyte Macrophage Colony-Stimulating Factor; HIF-1a - Hypoxia-inducible factor; IDH - Isocitrate dehydrogenase; IL-7 - Interleukin 7; IL-15 - Interleukin 15; MGMT - 0-6-methylguanine-DNA methyltransferase; MTIC - 5-(3-methyltriazen-1-yl) imidazole-4-carboxamide; PCP Pneumocystis Carinii; RT - radiotherapy; TMZ - Temozolomide; VCR - Vincristine; VEGF - Vascular endothelial growth factor; VEGFR 1 - Vascular endothelial growth factor receptor 1; VEGFR 2 - Vascular endothelial growth factor receptor 2

\section{- Streszczenie}

Wprowadzenie i cel pracy. Glejaki mózgu są zróżnicowaną grupą nowotworów układu nerwowego i charakteryzują się różnym przebiegiem choroby. W zależności od zaawansowania wpływają na całkowity czas przeżycia pacjentów i czas wolny od progresji choroby. Ze względu na zróżnicowany przebieg choroby istotny jest indywidualny schemat doboru terapii chemioterapeutykami. Celem pracy jest przedstawienie aktualnych informacji na temat najważniejszych cytostatyków stosowanych w leczeniu glejaka.

Metody przeglądu. Niniejsza praca jest przeglądem literatury dotyczącej dotychczasowej wiedzy i najnowszych doniesień naukowych na temat leków cytostatycznych stosowanych w terapii glejaka mózgu. Poszukując informacji do artykułu, przeszukano bazy: PubMed, Web of Science i Scopus, skupiając się na artykułach z ostatnich 5 lat. Słowa kluczowe i ich kombinacje użyte do wyszukiwania - zgodne z wyszukiwarką MeSH - były następujące: "glejak", "cytostatyki", "temozolomid", „prokarbazyna”, „lomustyna”, „winkrystyna”, „bewacyzumab".

Opis stanu wiedzy. W terapii glejaków najczęściej podaje się: temozolomid, lomustyna, prokarbazyna, winkrystyna czy bewacyzumab. Często stosuje się terapię skojarzoną opartą na schematach wielolekowych lub chemioterapię łączy się $z$ radioterapią. $W$ przeglądzie przedstawiono najważniejsze i najnowsze informacje o chemioterapeutykach stosowanych w leczeniu glejaków, tj.: temozolomidzie, lomustynie, prokarbazynie, winkrystynie oraz bewacyzumabie. Obecne terapie obejmują leki cytostatyczne, takie jak temozolomid (TMZ), terapię skojarzoną z winkrystyną (VCR), lomustyną (CNNU) i prokarbazyną, która jest określana jako terapia PCV. W przeglądzie zebrano informacje o mechanizmach działania, dotychczasowych badaniach naukowych nad terapią skojarzoną oraz o ewentualnych działaniach niepożądanych leków.

Podsumowanie. Najnowsze wyniki badań dotyczących interakcji leków potwierdzają potrzebę dalszego badania 
schematów terapii skojarzonych wykorzystujących zarówno nowo odkryte terapeutyki, jak i połączenie już poznanych leków.

\section{Słowa kluczowe}

glejak, temozolomid, prokarbazyna, lomustyna, winkrystyna, bewacyzumab

\section{INTRODUCTION AND OBJECTIVE}

The term glioma is used to describe a group of brain tumours that originate from sustentacular cells and glial cells. This group of tumours includes astrocytomas, oligodendrogliomas and mixed oligoastrocytomas. According to the WHO guidelines, gliomas can be classified according to their stage into low-grade and high-grade gliomas. Low-grade (non-malignant) gliomas include grades I and II which are characterized by a low grade of malignancy and occur more rarely than high-grade (malignant) gliomas. Grade I gliomas are the only gliomas that are cut-off from healthy tissue and whose treatment includes complete resection. The other grades of gliomas are diffuse and can be treated by as much surgical resection combined with chemo- or radiotherapy as possible [1]. High-grade gliomas include grades III and IV, which are considered to be among the most common and deadly CNS tumours. Gliomas represent the largest proportion of malignant brain tumours, thus overall incidence rates of the brain cancer reflect the incidence of gliomas [2]. The incidence of glioma in different regions of the world is shown in the Table 1 . Survival rate of malignant gliomas is low, most of the patients with III grade glioma die within 3-5 years [3].

Due to the aggressive course of malignant brain tumours, research is being conducted e worldwide to improve current therapies. Current therapies include cytostatic drugs, such temozolomide (TMZ), combination therapy with vincristine (VCR), lomustine (CNNU) and procarbazine, which is referred to as PCV therapy. Some of the cytostatic drugs used, e.g. bevacizumab (BEV), are still being tested in clinical trials. The aim of this review is to describe the cytostatic drugs used.

Table 1. Incidence of brain cancer in different regions of the world

\begin{tabular}{lc}
\hline World region & Age-standardized incidence rate (ASR) \\
\hline Europe & 5.5 per 100,000 persons \\
\hline North America & 5.3 per 100,000 persons \\
\hline Australia and New Zealand & 5.3 per 100,000 persons \\
\hline West Asia & 5.2 per 100,000 persons \\
\hline North Africa & 5.0 per 100,000 persons \\
\hline South-Central Asia & 1.8 per 100,000 persons \\
\hline Sub-Saharan Africa & 0.8 per 100,000 persons \\
\hline Oceania (without Australia and New & 0.5 per 100,000 persons \\
Zealand) & \\
\hline
\end{tabular}

\section{REVIEW METHODS}

This review of previous knowledge and the latest scientific reports was undertaken by searching the publication databases PubMed, Web of Science and Scopus, focusing mainly on articles from the last five years. The key words and their combination used for the search were consistent with the MeSH (Medical Subject Headings) browser: glioma, cytostatic agents, temozolomide, procarbazine, lomustine, vincristine, bevacizumab.

\section{STATE OF KNOWLEDGE}

Temozolomide. Temozolomide (TMZ) is one of the most commonly used chemotherapeutic drugs used in brain glioma therapy. Due to the small size of TMZ (194 Da) and lipophilic nature, TMZ easily crosses the blood-brain barrier. With standard oral dousing $\left(150-200 \mathrm{mg} / \mathrm{m}^{2}\right.$ on a $1-5$ every 4 week schedule), TMZ is $100 \%$ bioavailable [1]. However, research has shown that in more than a half of patients, TMZ therapy is ineffective due to characteristic resistance to the agent. TMZ resistance is related with the appearance of O-6-methylguanine-DNA methyltransferase (MGMT), DNA repair protein which reduces the effectiveness of TMZ. Inhibition of MGMT gene expression increases the efficacy of TMZ therapy. Studies have been performed to overcome resistance to TMZ trough changes in the dosing schedule, although they have not been confirmed by any clinical trials [1].

TMZ is classified as an alkylating substance. At $\mathrm{pH}<7$, TMZ is absorbed unchanged; therefore, the main route of administration is oral. However, at alkaline $\mathrm{pH}$ TMZ decomposes, which leads to the formation of 5-(3-methyltriazen-1-yl) imidazole-4-carboxamide (MTIC) and a methyldiazonium cation. The methyldiazonium cation adds methyl groups to the guanine at position N7 in rich regions into guanine, adenine at position $\mathrm{N}$, and guanine rests at position $\mathrm{O} 6[4,5]$.

The cytotoxicity of TMZ is mainly related to the $\mathrm{O} 6$ position change which can be corrected by MGMT. Cellular cytotoxicity is demonstrated by methylated 06 guanine rests; therefore, MGMT suppress the cytotoxic activity of TMZ. Guanine O6 methylation destabilizes the hydrogen bond between guanine and cytosine, resulting in incorrect binding of methylated guanine to thymine during DNA replication. The DNA repair mechanism during replication recognizes abnormal binding and aims to repair mismatches. However, the incorrect binding is repaired only in a new DNA strand and remains in the original strand, leading to repeated attempts to repair the strand, known as the 'futile cycle'. Unrepaired changes in the DNA strands are the reason of cell apoptosis $[4,5,6]$.

Treatment of glioma with TMZ is often undertaken in combination with radiotherapy (RT), prolonging the overall survival of patients. TMZ has been shown to be ineffective in combination therapy with other chemotherapeutics. Kim et al. proved the toxic effects of TMZ in combination with nimustine, carmustine and limustine [7]. The studies showed that patients treated with TMZ in combination with RT had reduced levels of T lymphocytes (CD4+ and CD8+). Additionally, it did not show the desired anti-cancerogenic effect used in combination therapy with small-molecule inhibitors. Studies on the use of TMZ in combination therapy are still ongoing. Phase III clinical trials have shown that 
despite an increased dose of TMZ, the therapy did not provide significant results compared to standard dosing. The effect of TMZ in a metronomic therapy scheme was also studied among elderly patients unresponsive to the standard treatment regimen. Furthermore, it was speculated that there was a reduced risk of TMZ-resistant tumour cells. This treatment regimen showed a reduced rate of angiogenesis of tumour cells NK (CD56+), B lymphocytes. TMZ in monotherapy did not significantly reduce CD8+ cell numbers [8].

TMS-induced lymphopenia increases cytokine levels and proliferation factors such as interleukin 7 (IL-7) and interleukin 15 (IL-15). Cytokines that increase lymphocyte proliferation are tumour suppressors [1].

Combination therapy of TMZ with granulocytemacrophage colony-stimulating factor (GM-CSF) showed increased proliferation of B-lymphocytes and a reduced number of tumour suppressors. Use of TMZ may cause release of tumuor antigens that are picked up by dendritic cells and presented to T lymphocytes. TMZ fusion with dendritic cells stimulated by tumour antigen increases progression free survival. To sum-up, TMZ combined with RT increases immune system activation; however, this effect is depends on the timing and dose of treatment [9].

The use of TMZ may cause nausea, vomiting and hepatotoxicity. Occasionally, allergic skin reactions are observed. TMZ therapy is accompanied by opportunistic infections, such as Pneumocystis carinii (PCP). Therapy with higher dose of TMZ should include prophylaxis of PCP infection with cotrimoxazole. TMZ therapy is not indicated for pregnant or lactating women $[1,10]$.

Bevacizumab. Bevacizumab (BEV) is a recombinant drug synthesized in the ovary cells of the Chinese hamster. It is a monoclonal antibody directed against vascular endothelial growth factor A (VEGF-A) [11]. BEV is used in a combination therapy regimen with other chemotherapeutics for the treatment of colon, ovarian, cervical, peritoneal and breast cancers. Recent studies indicate the possibility of using BEV in the treatment of progressive, recurrent or progressive brain gliomas. In 2009, after promising results from phase II clinical trial, it was registered as a drug for use in patients with progressive glioma for whom previous treatments have failed. However, the drug has only been registered in the USA and Canada, in Europe it has not been approved for use in patients with glioma due to the lack of standardized clinical trials $[12,13]$.

BEV inhibits tumour cells angiogenesis which directly affects the inhibition of proliferation and tumour growth caused by reduced access to nutrients. BEV binds to VEGF-A which prevents the binding of VEGF-A with tyrosine kinases of the VEGF receptor (VEGFR1, VEGFR2) [14]. The mechanism of BEV action is shown in Figure 1. In tumour cells, VEGF-A is over-expressed which leads to increased angiogenesis and tumour proliferation. VEGF-A overexpression indicates rapid cancer progression. Patients with VEGF over-expression have a shorter overall survival rate. In addition, BEV causes a decrease in vascular permeability, while a decrease in the rate of blood flow through tumur blood vesselswais observed with increased dosing [12]. In histopathological studies of resected brain tumour tissues in patients treated with $\mathrm{BEV}$, a decrease or even disappearance of VEGF-A expression was observed. Furthermore, BEV has been shown to have anti-edematous effects [15].

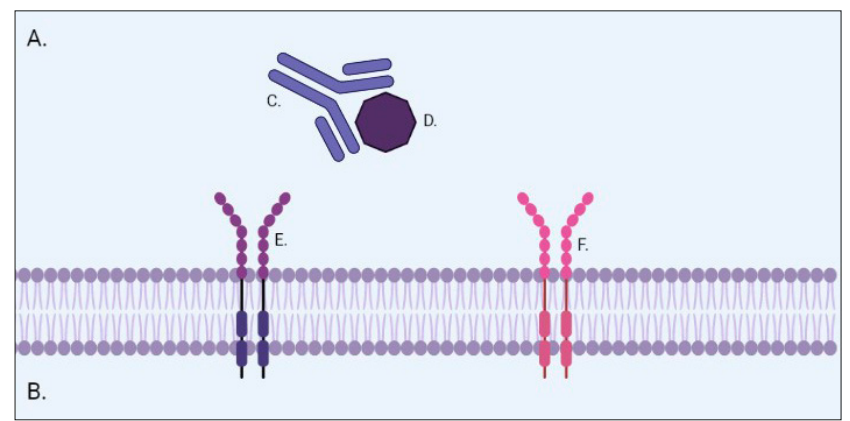

Figure 1. Scheme of action of bevacizumab (C) in the blood (A), which binds VEGF-A (D), thereby blocking the connection of VEGF-A to VEGFR-1 (E) and VEGFR-2 (F) receptors, which inhibits the proliferation and growth of endothelial cells (B)

Because of the lack of documented anti-cancer efficacy of $\mathrm{BEV}$ at low doses and its sensitivity to proteolytic enzymes, $\mathrm{BEV}$ is administered only intravenously at 2- or 3-week intervals. The dosage frequency and concentration in the solution depends on the type and stage of cancer. There is no need to modify the dosage in patients over 65 years of age. The safety of BEV in patients with nephrological diseases, as well as in patients with hepatic impairment, has not been established. BEV is safe for children and teenagers. Animal studies have shown a possible inhibitory effect on angiogenesis in the foetus; therefore, BEV cannot be used in pregnant women. In addition, BEV should not be used by lactating women due to the possibility of the drug passing into the milk and inhibiting the growth and development of the child [16]. Initial administration of the drug by intravenous infusion should be carried out gradually, and the infusion should be discontinued if symptoms of BEV intolerance occur $[11,17]$. BEV does not provide any statistically significant change of other chemotherapeutics pharmacokinetics; therefore, there are many potential opportunities to combine BEV's with other drug $[10,15]$.

$\mathrm{BEV}$ is used mainly in the treatment of recurrent brain tumours. Significant prolongation of progression free survival has been demonstrated in combined therapy of $\mathrm{BEV}$ with lomustine. Studies continue to be conducted on the efficacy of using BEV in combination with other drugs, although those conducted to-date have not shown any increase in progression free survival, compared to other chemotherapeutics. BEV is approved in the USA by the Food and Drug Administration (FDA) for the treatment of recurrent brain tumours, but is still not approved by the European Medicines Agency (EMA) due to the lack of statistically significant clinical trial results [12]. However, the 'Avastin in Glioblastoma' (AVAglio) study sponsored by F. Hoffmann-La Roche showed that the use of BEV reduces the need for treatment with glucocorticoids [18].

The most serious side-effects of using BEV are gastrointestinal perforations, haemorrhages, including pulmonary haemorrhages, and haemoptysis. The most common sideeffects of BEV are neutropenic fever, leukopenia, neutropenia, thrombocytopenia, taste disorders, blood clotting disorders and proteinuria. An increased incidence of ovarian failure has been observed in women treated with BEV; however, this effect was reversible after discontinuation of $\operatorname{BEV}[10,16]$.

Research has been carried out on the association of BEV with a vaccine directed against the epidermal growth factor receptor type III- EGFvIII (rindopepimut). The expression 
of EGFvIII is characteristic of malignant glioma phenotypes and is not found in normal tissues. Phase II trial results showed that association of BEV with rindopepimut may help slow tumour progression and prolong overall survival, compared with the use BEV alone. However, due to unclear action of rindopepimut and the as yet unexplained process of spontaneous disappearance of EGFRvIII in recurrent glioma cells, this therapy still requires further study [19].

Lomustine. Lomustine (CCNU) is the second most commonly used cytostatic drug, after TMZ, in the treatment of brain gliomas. In Europe, CCNU is the standard of care for recurrent brain tumours. CCNU is a component of PCV therapy, which is the most commonly undertaken therapy for the treatment of low-grade gliomas with isocitrate dehydrogenase (IDH) mutation [20]. CNU is a substance from the group of nitrosoureas and is classified as an alkylating cytostatic. CCNU cause alkylation of DNA, RNA and can cause cross-linking of DNA. CCNU is both cell cycle dependent and independent. Alkylation caused by CCNU interferes with the normal functioning of the cancer cell, leading to regression of disease. However, one of the most important mechanisms of TMZ action is induction of O6-chloerthylguanine formation, which can be reversed by the action of O6-methylguanine DNA methyltransferase. CCNU is also an enzyme inhibitor. This action is achieved by the carbomyelination of amino acids that build protein enzymes [21].

CCNU is a steroid agent, which is able to cross the bloodbrain barrier. CCNU is administered orally at intervals of 6-8 weeks. CCNU show a delayed myelosuppressive effect [21], and is commonly used in PCV combined therapy with vincristine and procarbazine. However, recent studies has shown the possibility of using CCNU in monotherapy in recurrent brain tumours or in chemotherapy combined with TMZ, as well as the possibility of extending the therapy using only CCNU [1].

The main side-effect of CCNU use is cumulative bone marrow suppression leading most often to thrombocytopenia, less often neutropenia and lymphocytopenia [1,21]. This causes a delayed decrease in blood cell counts after completion of CCNU chemotherapy. If haematological symptoms of CCNU use occur, the dose of the drug should be reduced or stopped completely [21].

Vincristine. Vincristine (VCR) is a natural compound derived from the plant Catharanthus roseus, belonging to the group of alkaloids. VCR has a dimeric structure, made of a combination of catharanthin and vindoline [22]. VCR molecules are much bigger than TMZ molecules ( 825 $\mathrm{Da})$, VCR are prone to transport by the Mrp1 and Pgp transport proteins. Because of that, unlike CCNU and TMZ, VCR is characterized by low bioavailability, with low penetration of the blood-brain barrier. What is more, VCR does not penetrate the tumour tissue. VCR is used in the chemotherapy of low-advanced gliomas and other CNS tumours [23].

The action of VCR is based on inhibition of cancer cell division. VCR binds to the microtubules that build karyokinetic spindles at their ends or, less commonly, along their length. Depending on the concentration of VCR in the cell, microtubules disintegrate and destroy the spindle (high concentrations $>1-2 \mu \mathrm{mol}$ ), or stabilize the microtubules (low concentrations $<1 \mu \mathrm{mol})$. This results in inhibition of mitosis, which causes apoptosis of cancer cells [22].

In monotherapy or combined therapy with PCV, VCR can cause a peripheral neuropathy. Studies have shown that neuropathy induced by VCR can be associated with too high single doses of VCR (more than $2 \mathrm{mg} / \mathrm{m}^{2}$ ), too high total amount of VCR administered during combined therapy, combine VCR with inhibitor CYP3A4 (e.g. ketoxonazol) or the background of patients [24]. Neuropathies was more common in patients of African than European descent. The association of VCR-induced neuropathy with the origin of the patients, allows the hypothesis of a genetic determinant of this type of neuropathy [25].

Procarbazine. Procarbazine belongs to the group of alkylating cytostatic. Procarbazine is a chemotherapeutic agent, most commonly combined with CCNU and VCR in PCV combination therapy [26]. Procarbazine is one of several available drugs used orally in the treatment of high-grade glioma when radiotherapy and nitrosourea therapy have proved insufficient [27]. Procarbazine is not recommended as first-line treatment in monotherapy for brain glioma, due to its toxic effects on the bone marrow due to its toxic effects on the bone marrow. The side effects of procarbazine may induce the formation of secondary tumors. Therefore, procarbazine should not be used to treat low-grade glioma [28]. Studies have shown that chemotherapy based on procarbazine, modified efficacy to the use of low-dose TMZ as rescue treatment for recurrent brain glioma [29].

The mechanism of procarbazine action involves slowing down or inhibiting the development of tumour cells in brain glioma. Studies have shown that procarbazine can be an inhibitor of the transmethylation of methionine methyl groups in tRNA. Because of that, tRNA defect can inhibit protein synthesis, leading to inhibition of DNA and RNA synthesis. Procarbazine undergoes an oxidation reaction that occurs spontaneously under the influence of oxygen, causing the formation of hydrogen peroxide, which can damage DNA [30].

Using procarbazine may cause nausea, vomiting, loss of appetite, an allergic skin rash [32] and may cause reduced fertility [1], [31]. Procarbazine is transformed to azoprocarbazine by liver enzymes, ewhich is the reason for the strong hepatotoxicity of procarbazine.

PCV therapy. PCV therapy is a combined therapy using VCR, CCNU and procarbazine. PCV therapy is recommended as an adjunctive therapy, or therapy used to treat recurrent scapulopoma, anaplastic staphyloma, multiforme glioblastoma and low-grade glioblastoma [33]. It is the most common therapy for patients with low-grade gliomas, which most commonly affect people between the ages of 35-4; hence, this therapy is taken up among people in this age. Adjuvant therapy is RT [34]. Reduced efficacy of PCV therapy has been reported among patients over 40 years of age. In this group of patients, the dose has to be reduced or the next dose delayed. In the group of patients over 40 years of age, multiple side- effects and worse chemotherapeutic tolerance were observed, as well as reduced levels of sensitivity to treatment [35]. The combination of these two treatment regimens conditions the prolongation od overall survival and progression of free survival. the IDH1 mutation status, its length and dosage, is important for the choice of therapy, [36]. 
The IDH enzyme, coded by the IDH1 and IDH2 genes, is involved in mitochondrial oxidative phosphorylation, lipogenesis and glutamine metabolism, and regulates the cellular redox state $[37,38]$. IDH enzyme catalyzes the oxidative decarboxylation of isocitrate to a-ketoglutarate. In addition, IDH enzyme is responsible for the reduction of NADP+ [39] and has an important role in maintaining the antioxidant system in the cell, which prevents the development of tumour cells. However, IDH2 controls the tricarboxylic acid cycle, thereby regulating the energy level of the cell [40]. IDH1 and IDH2 genes mutations appear in chronic lymphocytic leukemia, low-grade and secondary glioma. Assessment of $I D H$ mutation status is an important prognostic factor determining PCV treatment scheme [41, 42].

IDH mutations also results in the inhibition of glioma stem cells differentiation with increased VEGF expression levels. It also affects the excessive synthesis of hypoxia-inducible factor - 1a (Hif-1a), which promotes glioma invasion ultimately leading to glioma progression [43]. A differential correlation has been shown between the IDH mutation stage, glioma stage, parameters of overall survival time, progressionfree survival time, and response to therapy. Evaluation of IDH mutation status is essential when initiating RT and PCV therapy. Patients with IDH mutation showed longer progression-free survival time and overall survival time after PCV treatment [44].

PCV therapy is administered with procarbazine at $60 \mathrm{mg} / \mathrm{m}^{2}, \mathrm{CCNU}$ at $110 \mathrm{mg} / \mathrm{m}^{2}$ and VCR at $1.4 \mathrm{mg} / \mathrm{m}^{2}$, in cycles every 6-8 weeks. Procarbazine is given as a single dose per day or as 3-4 divided doses. CCNU is given as single dose, one hour before eating or 2 hours after eating. VCR is given intravenously [33].

Side-effects of PCV therapy combined with RT were observed in each of the study groups $[45,46,47]$. The most common side-effects were bone marrow toxicity, diarrhea, vomiting, fatigue and hepatotoxicity. Hepatotoxicity is mainly exhibited by procarbazine and VCR, as well as by anticonvulsants often used during chemotherapy [45]. One of the most serious complication of RT and PCV therapy use is myelosuppression, characterized by a decrease in neutrophil and platelet levels. The incidence of myelosuppression was 51\%
[47]. Grade III anaemia and a decrease in CD4+ lymphocytes were also noticed [32] and neurotoxicity caused by vincristine also observed [49]. A skin rash also occurred [31, 35].

In many patients, therapy had to be discontinued due to a multitude of side-effects. It happened sometimes that doses had to be given at longer intervals to reduce drug toxicity $[45,48]$. The most common reason for delaying dosing or discontinuing therapy was a significant decrease of CD4+ lymphocytes $(<200)$ and the occurrence of neurotoxicity. In $38.6 \%$ of patients an incomplete cycle had to be performed due to discontinuation. In patients with elevated levels of alanine aminotransferase, a marker of liver injury, procarbazine was excluded from the treatment regimen [32].

No specific benefit of PCV therapy has been demonstrated compared to TMZ treatment. TMZ treatment has less toxicity and easier dosing. PCV causes myelosuppression, skin allergy, and sometimes mood changes. Although many side-effects occur during PCV therapy, it is possible to eliminate them by reducing the dose or discontinuing the drug. Previous studies suggest the choice of PCV chemotherapy due to its easily manageable toxicity and documented efficacy [44]. The described drugs, therefore, cause many side-effects and are also characterized by different efficacy. Table 2 summarizes the basic advantages and disadvantages of the described cytostatics.

\section{SUMMARY}

Gliomas are a highly heterogenous group of cancers, characterized by various courses of the disease, various time of overall survival and progression free survival. The course of disease is different for each patient. If the location of glioma allows surgical removal of the tumour mass, this is the first action taken. If surgical procedure carries a high surgical risk, or if the glioma is located in hard-to-reach place, the indication is for stereotactic biopsy. It is essential to start therapy with chemotherapeutics, which are often combined with RT. Chemotherapy reduces risk of recurrence. Gliomas are not among the most common cancers in the population, but they are the most common cancers of CNS,

Table 2. Advantages and disadvantages of temozolomide, bevacizumab, lomustine, vincristine and procarbazine

\begin{tabular}{|c|c|c|}
\hline Drugs & Advantages & Disadvantages \\
\hline $\begin{array}{l}\text { Temozolomide } \\
\text { (TMZ) }\end{array}$ & $\begin{array}{l}\text { - Easily crosses the blood-brain barrier }[1,50] \text {. } \\
\text { - } 100 \% \text { bioavailability with standard oral dosing [1]. } \\
\text { - Increases progression-free survival [9] }\end{array}$ & $\begin{array}{l}\text { - Approximately } 50 \% \text { of patients have resistance to the TMZ [50]. } \\
\text { - TMZ is ineffective in combination therapy [7]. } \\
\text { - May causes nausea, vomiting, hepatotoxicity, and occasionally allergic skin } \\
\text { reactions }[1,10] \text {. }\end{array}$ \\
\hline $\begin{array}{l}\text { Bevacizumab } \\
\text { (BEV) }\end{array}$ & $\begin{array}{l}\text { - BEV inhibits tumour cells angiogenesis which directly affect } \\
\text { inhibition of proliferation and tumour growth. } \\
\text { - BEV has anti-edematous effect [15]. } \\
\text { - BEV is safe for children and teenagers [16]. } \\
\text { - BEV reduces the need for treatment with glucocorticoids [18]. } \\
\text { - BEV in a combination with lomustine demonstrates } \\
\text { prolongation of progression free-survival [12]. }\end{array}$ & $\begin{array}{l}\text { - Sensitivity to proteolytic enzymes [16]. } \\
\text { - Cannot be used in pregnant women [16]. } \\
\text { - Can pass into breast milk and impair a child's growth [16] } \\
\text { - BEV may cause neutropenic fever, leukopenia, neutropenia, thrombocytopenia, } \\
\text { taste disorders, blood clotting and proteinuria }[10,16] \text {. }\end{array}$ \\
\hline $\begin{array}{l}\text { Lomustine } \\
\text { (CCNU) }\end{array}$ & - CCNU is able to cross blood- brain barrier [21]. & $\begin{array}{l}\text { - CCNU show a delayed myelosuppressive effect [21. } \\
\text { - } C \text { CNU causes thrombocytopenia, less of neutropenia and lymphocytopenia }[1,21] \text {. }\end{array}$ \\
\hline $\begin{array}{l}\text { Vincristine } \\
\text { (VCR) }\end{array}$ & $\begin{array}{l}\text { - VCR is used in the chemotherapy of low-advanced glioma } \\
\text { and other CNS tumours [23] }\end{array}$ & $\begin{array}{l}\text { - Low bioavailability with low penetration of the blood-brain barrier [23]. } \\
\text { - In monotherapy or combined therapy with PCV, VCR can cause peripheral } \\
\text { neuropathy [25]. }\end{array}$ \\
\hline Procarbazine & $\begin{array}{l}\text { Procarbazine is one of several available drugs used orally in } \\
\text { the treatment of high-grade glioma when radiotherapy and } \\
\text { nitrosourea therapy have proofed insufficient [27]. }\end{array}$ & $\begin{array}{l}\text { - Procarbazine has toxic effects on bone marrow [28]. } \\
\text { - Procarbazine may induce the formation of secondary tumours [28]. } \\
\text { - Cause nausea, vomiting, loss of appetite, and may cause reduced fertility [31] } \\
\text { - Procarbazine is characterized by strong hepatotoxicity [32], }\end{array}$ \\
\hline
\end{tabular}


which are characterized by an aggressive course, leading to death within a short period of time.

Furthermore, the recurrences of tumours after surgical resection is often reported. Due to the various courses of the disease, an individual therapy scheme is important. Therefore, new discoveries and ongoing clinical trials on new chemotherapeutic agents which can expand the scope of treatment options are important. Moreover, in order to maximize the improvement of overall survival, progression free survival time, patient's comfort and minimize the risk of complications, combined therapy is used. Many chemotherapeutic agents are used which can interact with each other to increase the effectiveness of therapy. For this reason, research on new combined therapies using both newly-discovered therapeutics and the combination of existing ones may turn out to be significant.

\section{REFERENCES}

1. Taal W, Bromberg JE, van den Bent MJ. Chemotherapy in glioma. CNS Oncol. 2015; 4(3): 179-92. doi: 10.2217/cns.15.2

2. Ostrom QT, Gittleman H, Stetson L, et al. Epidemiology of gliomas. Cancer Treat Res. 2015; 163: 1-14. doi: 10.1007/978-3-319-12048-5_1

3. Wang W, Shi G, Ma B, et al. Chemotherapy for Adults with Malignant Glioma: A Systematic Review and Network Meta-Analysis. Turk Neurosurg. 2017; 27(2): 174-181. doi: 10.5137/1019-5149.JTN.15462-15.0

4. Chen X, Zhang M, Gan H, et al. A novel enhancer regulates MGMT expression and promotes temozolomide resistance in glioblastoma. Nat Commun. 2018; 9(1): 2949. doi: 10.1038/s41467-018-05373-4

5. Choi S, Yu Y, Grimmer MR, et al. Temozolomide-associated hypermutation in gliomas. Neuro Oncol. 2018; 20(10): 1300-1309. doi: 10.1093/neuonc/noy016

6. Kaina B, Christmann M. DNA repair in personalized brain cancer therapy with temozolomide and nitrosoureas. DNA Repair (Amst). 2019; 78: 128-141. doi: 10.1016/j.dnarep.2019.04.007

7. Kim IH, Park CK, Heo DS, et al. Radiotherapy followed by adjuvant temozolomide with or without neoadjuvant ACNU-CDDP chemotherapy in newly diagnosed glioblastomas: a prospective randomized controlled multicenter phase III trial. J Neurooncol. 2011; 103(3): 595-602. doi: 10.1007/s11060-010-0427-y

8.Xu X, Stockhammer F, Schmitt A, et al. Therapeutical doses of temozolomide do not impair the function of dendritic cells and CD8+ T cells. Int J Oncol. 2012; 40(3): 764-72. doi: 10.3892/ijo.2011.1269

9. Ellsworth S, Balmanoukian A, Kos F, et al. Sustained CD4+ T cell-driven lymphopenia without a compensatory IL-7/IL-15 response among high-grade glioma patients treated with radiation and temozolomide. Oncoimmunology. 2014; 3(1): e27357. doi: 10.4161/onci.27357

10. Matsuda M, Yamamoto T, Ishikawa E, et al. Profile Analysis of Chemotherapy-induced Nausea and Vomiting in Patients Treated with Concomitant Temozolomide and Radiotherapy: Results of a Prospective Study. Neurol Med Chir (Tokyo). 2015; 55(9): 749-55. doi: 10.2176/nmc. oa.2014-0413

11. Charakterystyka Produktu Leczniczego Avastin: https://www.ema. europa.eu/en/documents/product-information/avastin-epar-productinformation_pl.pdf [access: 25.04.2021]

12. Kim MM, Umemura Y, Leung D. Bevacizumab and Glioblastoma: Past, Present, and Future Directions. Cancer J. 2018; 24(4): 180-186. doi: 10.1097/PPO.0000000000000326

13. Chinot OL, de La Motte Rouge T, Moore N, et al. AVAglio: Phase 3 trial of bevacizumab plus temozolomide and radiotherapy in newly diagnosed glioblastoma multiforme. Adv Ther. 2011; 28(4): 334-40. doi: 10.1007/s12325-011-0007-3

14. Jahangiri A, De Lay M, Miller LM, et al. Gene expression profile identifies tyrosine kinase c-Met as a targetable mediator of antiangiogenic therapy resistance. Clin Cancer Res. 2013; 19(7): 1773-83. doi: 10.1158/10780432.CCR-12-1281

15. Tamura R, Tanaka T, Miyake K, et al. Histopathological investigation of glioblastomas resected under bevacizumab treatment. Oncotarget. 2016; 7(32): 52423-52435. doi: 10.18632/oncotarget.9387

16. Ghiaseddin A, Peters KB. Use of bevacizumab in recurrent glioblastoma. CNS Oncol. 2015; 4(3): 157-69. doi: 10.2217/cns.15.8 17.van den Bent MJ, Klein M, Smits M, et al. Bevacizumab and temozolomide in patients with first recurrence of WHO grade II and III glioma, without $1 \mathrm{p} / 19 \mathrm{q}$ co-deletion (TAVAREC): a randomised controlled phase 2 EORTC trial. Lancet Oncol. 2018; 19(9): 1170-1179. doi: 10.1016/S1470-2045(18)30362-0

18. Chinot OL, Wick W, Mason W, et al. Bevacizumab plus radiotherapytemozolomide for newly diagnosed glioblastoma. N Engl J Med. 2014; 370(8): 709-22. doi: 10.1056/NEJMoa1308345

19. Platten M. EGFRvIII vaccine in glioblastoma-InACT-IVe or not ReACTive enough? Neuro Oncol. 2017; 19(11): 1425-1426. doi: 10.1093/ neuonc/nox 167

20.van den Bent MJ, Brandes AA, Taphoorn MJ, et al. Adjuvant procarbazine, lomustine, and vincristine chemotherapy in newly diagnosed anaplastic oligodendroglioma: long-term follow-up of EORTC brain tumor group study 26951. J Clin Oncol. 2013; 31(3): 344-50. doi: 10.1200/JCO.2012.43.2229

21. Weller M, Le Rhun E. How did lomustine become standard of care in recurrent glioblastoma? Cancer Treat Rev. 2020; 87: 102029. doi: 10.1016/j.ctrv.2020.102029

22. Gurgul A. Substancje pochodzenia roślinnego w terapii nowotworów. Postępy Fitoter. 2017; 18(3): 203-208.

23. De Witt M, Gamble A, Hanson D, et al. Repurposing Mebendazole as a Replacement for Vincristine for the Treatment of Brain Tumors. Mol Med. 2017; 23: 50-56. doi: 10.2119/molmed.2017.00011.

24. Brings A, Lehmann ML, Foerster KI, et al. Perpetrator effects of ciclosporin (P-glycoprotein inhibitor) and its combination with fluconazole (CYP3A inhibitor) on the pharmacokinetics of rivaroxaban in healthy volunteers. Br J Clin Pharmacol. 2019; 85(7): 1528-1537. doi: 10.1111/bcp. 13934

25. Diouf B, Evans WE. Pharmacogenomics of Vincristine-Induced Peripheral Neuropathy: Progress Continues. Clin Pharmacol Ther. 2019; 105(2): 315-317. doi: 10.1002/cpt.1209

26. Hafazalla K, Sahgal A, Jaja B, et al. Procarbazine, CCNU and vincristine (PCV) versus temozolomide chemotherapy for patients with low-grade glioma: a systematic review. Oncotarget. 2018; 9(72): 33623-33633. doi: 10.18632/oncotarget. 25890

27. Parasramka S, Talari G, Rosenfeld M, et al. Procarbazine, lomustine and vincristine for recurrent high-grade glioma. Cochrane Database Syst Rev. 2017; 7(7): CD011773. doi: 10.1002/14651858.CD011773.pub2

28. Goernera R, Bogdahn U, Hau P. Procarbazine--a traditional drug in the treatment of malignant gliomas. Curr Med Chem. 2008; 15(14): 1376-87. doi: 10.2174/092986708784567707

29. Kim SH, Yoo H, Chang JH, et al. Procarbazine and CCNU Chemotherapy for Recurrent Glioblastoma with MGMT Promoter Methylation. J Korean Med Sci. 2018; 33(24): e167. doi: 10.3346/jkms.2018.33.e167

30. Armand JP, Ribrag V, Harrousseau JL, Abrey L. Reappraisal of the use of procarbazine in the treatment of lymphomas and brain tumors. Ther Clin Risk Manag. 2007; 3(2): 213-24. doi: 10.2147/tcrm.2007.3.2.213

31. Wang $\mathrm{R}$, Zhang $\mathrm{C}$, Zheng $\mathrm{C}$, et al. Introduction of Z-GP scaffold into procarbazine reduces spermatoxicity and myelosuppression. Bioorg Chem. 2019; 83: 461-467. doi: 10.1016/j.bioorg.2018.11.011

32. Jutras G, Bélanger $\mathrm{K}$, Letarte $\mathrm{N}$, et al. Procarbazine, lomustine and vincristine toxicity in low-grade gliomas. Curr Oncol. 2018; 25(1): e33-e39. doi: $10.3747 /$ co. 25.3680

33. Solimando DA Jr, Waddell JA. Procarbazine, Lomustine, and Vincristine (PCV) Regimen for Central Nervous System Tumors. Hosp Pharm. 2017; 52(2): 98-104. doi: 10.1310/hpj5202-98

34. Donovan LE, Lassman AB. Chemotherapy Treatment and Trials in Low-Grade Gliomas. Neurosurg Clin N Am. 2019; 30(1): 103-109. doi: 10.1016/j.nec.2018.08.007

35. Keogh RJ, Aslam R, Hennessy MA, et al. One year of procarbazine lomustine and vincristine is poorly tolerated in low grade glioma: a real world experience in a national neuro-oncology centre. BMC Cancer. 2021; 21(1): 140. doi: 10.1186/s12885-021-07809-5

36. Buckner JC, Shaw EG, Pugh SL, et al. Radiation plus Procarbazine, CCNU, and Vincristine in Low-Grade Glioma. N Engl J Med. 2016; 374(14): 1344-1355. doi: 10.1056/nejmoa1500925

37. Mondesir J, Willekens C, Touat M, de Botton S. IDH1 and IDH2 mutations as novel therapeutic targets: current perspectives. J Blood Med. 2016; 7: 171-80. doi: 10.2147/JBM.S70716

38. Han S, Liu Y, Cai SJ, et al. IDH mutation in glioma: molecular mechanisms and potential therapeutic targets. Br J Cancer. 2020; 122(11): 1580-1589. doi: 10.1038/s41416-020-0814-x

39. Li F, He X, Ye D, et al. NADP(+)-IDH Mutations Promote Hypersuccinylation that Impairs Mitochondria Respiration and Induces Apoptosis Resistance. Mol Cell. 2015; 60(4): 661-75. doi: 10.1016/j. molcel.2015.10.017 
40. Waitkus MS, Diplas BH, Yan H. Isocitrate dehydrogenase mutations in gliomas. Neuro Oncol. 2016; 18(1) 16-26. doi: 10.1093/neuonc/nov136

41. Krell D, Assoku M, Galloway M, et al. Screen for IDH1, IDH2, IDH3, D2HGDH and L2HGDH mutations in glioblastoma. PLoS One. 2011; 6(5): e19868. doi: 10.1371/journal.pone.0019868

42. Miller JJ, Shih HA, Andronesi OC, Cahill DP. Isocitrate dehydrogenasemutant glioma: Evolving clinical and therapeutic implications. Cancer. 2017; 123(23): 4535-4546. doi: 10.1002/cncr.31039

43. Pientka FK, Hu J, Schindler SG, et al. Oxygen sensing by the prolyl-4hydroxylase PHD2 within the nuclear compartment and the influence of compartmentalisation on HIF-1 signalling. J Cell Sci. 2012; 125(Pt 21): 5168-76. doi: $10.1242 /$ jcs. 109041

44. Tom MC, Cahill DP, Buckner JC, et al. Management for Different Glioma Subtypes: Are All Low-Grade Gliomas Created Equal? Am Soc Clin Oncol Educ Book. 2019; 39: 133-145. doi: 10.1200/EDBK_238353

45. Irfan N, Samuel E, Rafi Ranjha F, et al. Toxicity Profile of Procarbazine Lomustine and Vincristine Chemotherapy in Low-Grade Glioma Retrospective Review. Cureus. 2020; 12(10): e11070. doi: 10.7759/ cureus. 11070
46. Buckner JC, Gesme D Jr, O’Fallon JR, et al. Phase II trial of procarbazine lomustine, and vincristine as initial therapy for patients with low-grade oligodendroglioma or oligoastrocy toma: efficacy and associations with chromosomal abnormalities. J Clin Oncol. 2003; 21(2): 251-5. doi: 10.1200/JCO.2003.06.023

47. McDuff SGR, Dietrich J, Atkins KM, et al. Radiation and chemotherapy for high-risk lower grade gliomas: Choosing between temozolomide and PCV. Cancer Med. 2020; 9(1): 3-11. doi: 10.1002/cam4.2686

48. Eckel-Passow JE, Lachance DH, Molinaro AM, et al. Glioma Groups Based on 1p/19q, IDH, and TERT Promoter Mutations in Tumors. N Engl J Med. 2015; 372(26): 2499-508. doi: 10.1056/NEJMoa1407279

49. Nama N, Barker MK, Kwan C, et al. Vincristine-induced peripheral neurotoxicity: A prospective cohort. Pediatr Hematol Oncol. 2020; 37(1): 15-28. doi: 10.1080/08880018.2019.1677832

50. Park SH, Kim MJ, Jung HH, et al. One-Year Outcome of Multiple BloodBrain Barrier Disruptions With Temozolomide for the Treatment of Glioblastoma. Front Oncol. 2020; 10: 1663. doi: 10.3389/fonc.2020.01663 